\title{
Anticancer activity of Nelumbo nucifera stamen extract in human colon cancer HCT-116 cells in vitro
}

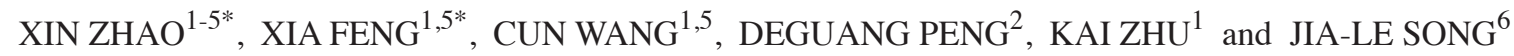 \\ ${ }^{1}$ Chongqing Collaborative Innovation Center for Functional Food, Chongqing University of Education, Chongqing 400067; \\ ${ }^{2}$ Chongqing Enterprise Engineering Research Center of Ba-lotus Breeding and Deep Processing, Chongqing 400041; \\ ${ }^{3}$ Chongqing Engineering Research Center for Functional Food; ${ }^{4}$ Chongqing Engineering Laboratory for Research \\ and Development of Functional Food; ${ }^{5}$ Department of Biological and Chemical Engineering, \\ Chongqing University of Education, Chongqing 400067; ${ }^{6}$ Department of Nutrition and Food Hygiene, \\ School of Public Health, Guilin Medical University, Guilin, Guangxi 541004, P.R. China
}

Received July 11, 2015; Accepted November 17, 2016

DOI: $10.3892 / \mathrm{ol} .2016 .5547$

\begin{abstract}
The aim of the present study was to investigate the anticancer activities of Nelumbo nucifera (Ba lotus) stamen ethanol crude extract (BLSEE) in human colon carcinoma HCT-116 cells. MTT assay, flow cytometry analysis and reverse transcription-polymerase chain reaction assay were employed to investigate the anticancer mechanisms of BLSEE $(100,200$ and $400 \mu \mathrm{g} / \mathrm{ml})$ in HCT-116 cells. BLSEE reduced HCT-116 cell proliferation in a dose-dependent manner. BLSEE treatment also significantly increased the sub-G1 population in HCT-116 cells $(\mathrm{P}=0.0020$ at $400 \mu \mathrm{g} / \mathrm{ml})$, as shown by flow cytometry assay. Following treatment with BLSEE, the mRNA levels of the apoptosis-associated factors Fas, Fas ligand, tumor necrosis factor-related apoptosis-inducing ligand, death receptor 4 (DR4), death receptor 5 (DR5), caspases 3, 8 and 9, and B-cell lymphoma-2 (Bcl-2) associated $\mathrm{X}$ protein were increased, and the expression of anti-apoptotic Bcl-2 and Bcl-extra large was decreased in HCT-116 cells. The mRNA levels of matrix metalloproteinase (MMP)-2, MMP-9, TIMP metallopeptidase inhibitor 1 and TIMP metallopeptidase inhibitor 2 were also regulated by BLSEE treatment. In addition, BLSEE was able to modulate
\end{abstract}

Correspondence to: Professor Deguang Peng, Chongqing Enterprise Engineering Research Center of Ba-lotus Breeding and Deep Processing, 13-9 Gaochuang Jinye, Jiulongpo, Chongqing 400041, P.R. China

E-mail: pengdeguang@163.com

Professor Jia-Le Song, Department of Nutrition and Food Hygiene, School of Public Health, Guilin Medical University, 109 Huancheng North 2 Road, Guilin, Guangxi 541004, P.R. China

E-mail: foods@live.cn

${ }^{*}$ Contributed equally

Key words: lotus stamen ethanol extract, HCT-116 cells, apoptosis, caspase family, inflammation the expression of inflammation-associated nuclear factor- $\kappa \mathrm{B}$, inhibitory $\kappa \mathrm{B} \alpha$, inducible nitric oxide synthase and cyclooxygenase 2 in HCT-116 cells. The present study clearly indicated the cytotoxicity of BLSEE in HCT-116 cells through induced cellular apoptosis. These results also suggested the BLSEE may be a powerful agent against colon cancer cells.

\section{Introduction}

Colorectal cancer (CRC) is one of the most frequently diagnosed cancers in the world. In the USA, CRC is the third most common malignant tumor, and there was an estimated 103,170 new cases of CRC throughout the country in 2014 (1). Previously, CRC has become the fourth most common malignant tumor, and the third leading cause of cancer-associated mortality in China (2). CRC also shows a high level of metastasis, and $25 \%$ of CRC patients that present with metastatic disease have a 5-year survival of only $10 \%$ (3). Surgical resection plus chemotherapy and/or radiation therapy are effective treatments for CRC in the clinic. However, chemotherapy and radiation therapy are commonly associated with serious side effects, including bone marrow suppression, nausea and vomiting, hair loss and loss of appetite (3). Enhancement of cancer cell apoptosis is a good strategy in the clinical treatment of cancer (4).

As classic apoptosis-associated factors, the B-cell lymphoma 2 (Bcl-2) family plays an important role in the regulation of cell apoptosis. The Bcl-2 family is generally divided into anti-apoptotic factors, including Bcl-2, Bcl-extra large (Bcl-xL) and Bcl-W, and proapoptotic factors, including Bcl-2-associated $\mathrm{X}$ protein (Bax), Bcl-2 associated agonist of cell death, Bcl-2 interacting mediator of cell death (Bim), Bcl-2 antagonist/killer 1 and p53 upregulated modulator of apoptosis $(5,6)$. In the extrinsic apoptosis pathway, the cell death receptor Fas/Fas ligand (FasL) system plays an important role to induce receptor-ligand mediated cell apoptosis, and also regulates the Fas-associated death domain (FADD) and caspase-8-mediated cell apoptosis (7). In apoptosis, the depolarization of the inner mitochondrial membrane potential causes the release of cytochrome $c$ (Cyto $c$ ) into the 
cytosol (8). The released Cyto $c$ also activates caspases by formation of a complex that induces the activation of apoptotic protease-activating factor-1 (Apaf-1) and procaspase-9. Furthermore, activated caspase- 8 and -9 cleaved the final executioner caspase-3, and directly induced the chromatin condensation and DNA fragmentation to promoting apoptosis in cells $(9,10)$.

Traditional herbal medications are commonly used to treat colon cancer in the clinic (11-13). Lotus is traditionally used as a Chinese folk medicine to disperse the summer heat, and has shown numerous health benefits and pharmacological activities, including antioxidant (14), antidiarrheal (15), antiviral (16), anti-obesity (17-20), anti-angiogenic (21), hepatoprotective (22), immunomodulatory (23) and insulin secretagogue activity (24). Therefore, the present study focused on investigating the potential anticancer activity of Nelumbo nucifera (Ba lotus) stamen ethanol crude extract (BLSEE), and also to elucidate the mechanisms underlying its anticancer effects in human colon carcinoma HCT-116 cells.

\section{Materials and methods}

Chemical reagents. TRIzol reagent, OligodT ${ }_{18}$ primer, murine Moloney leukemia virus (MMLV) reverse transcriptase, RNase inhibitor, ethidium bromide (EtBr), and agarose were purchased from Invitrogen (Thermo Fisher Scientific, Inc., Waltham, MA, USA). All other reagents were of analytical grade and purchased from Sigma-Aldrich (Merck Millipore, Darmstadt, Germany).

BLSEE preparation. Fresh Ba lotus stamen purchased from Chongqing Enterprise Engineering Research Center of Ba-lotus Breeding and Deep Processing (Chongqing, China) were freeze-dried and then ground into a fine powder. In total, $100 \mathrm{~g}$ of powdered Ba lotus stamen was extracted twice with $1,000 \mathrm{ml}$ ethanol $(70 \%, \mathrm{v} / \mathrm{v})$ at $50^{\circ} \mathrm{C}$ for $1 \mathrm{~h}$. Subsequent to filtering, the sample extraction solution was condensed by vacuum rotary evaporator (Büchi Rotovapor RE 111; Büchi Labortechnik AG, Flawil, Switzerland) at $37^{\circ} \mathrm{C}$, freeze-dried and stored at $-80^{\circ} \mathrm{C}$ until further study.

Cell culture. Human colorectal HCT-116 cancer cells were purchased from the American Type Culture Collection (Manassas, VA, USA). The cells were routinely maintained in RPMI-1640 medium supplemented with 10\% (v/v) FBS, and $1 \%$ penicillin-streptomycin in a humidified $\mathrm{CO}_{2}$ incubator (model 3154; Forma Scientific, Inc., Marietta, OH, USA) with a $5 \% \mathrm{CO}_{2}$ atmosphere at $37^{\circ} \mathrm{C}$.

Cell viability assay. Cell viability was measured using an MTT assay. HCT-116 cells were seeded in 96-well plates (Nalge Nunc International, Rochester, NY, USA) at a density of $1 \times 10^{4}$ cells/well. Following a 24-h incubation, the cells were treated with the various concentrations (100, 200 and $400 \mu \mathrm{g} / \mathrm{ml}$ ) of BLSEE for $24 \mathrm{~h}$. Following incubation with BLSEE $0.5 \mathrm{mg} / \mathrm{ml}$ of MTT reagent $(100 \mu \mathrm{l})$ was added to each well and the cells were incubated in a humidified incubator at $37^{\circ} \mathrm{C}$ to allow the MTT to be metabolized. At total of $4 \mathrm{~h}$ later, formazan crystals were dissolved with dimethyl sulfoxide (100 $\mu 1$ in each well). Absorbance of the samples was measured at a wavelength of $540 \mathrm{~nm}$ using a microplate reader (model, 680; Bio-Rad Laboratories, Inc., Hercules, CA, USA).

Flow cytometry analysis. The BLSEE-treated HCT-116 cells were first collected following digestion with trypsin, washed twice with cold PBS, and resuspended in $2 \mathrm{ml}$ PBS. The DNA contents of the treated cells were stained with propidium iodide (PI) using a DNA staining kit (CycleTEST ${ }^{\mathrm{TM}}$ PLUS DNA reagent kit; Becton Dickinson, Franklin Lakes, NJ, USA), according to the manufacturer's protocol. Fluorescence intensity was determined using a FACScan flow cytometer (EPICS XL-MCL, Beckman Coulter KK, Brea, CA, USA) and analyzed using CellQuest software (Becton Dickinson).

Reverse transcription-polymerase chain reaction (RT-PCR) assay. Total RNA was isolated from BLSEE-treated HCT-116 cells using TRIzol reagent, according to the manufacturer's protocol, and centrifuged at $12,000 \times \mathrm{g}$ for $15 \mathrm{~min}$ at $25^{\circ} \mathrm{C}$ following the addition of chloroform $(200 \mu \mathrm{l})$. Isopropanol was added to the supernatant at a 1:1 ratio and the RNA was pelleted by centrifugation at $12,000 \mathrm{x} \mathrm{g}$ for $15 \mathrm{~min}$ at $4^{\circ} \mathrm{C}$. Subsequent to washing with ethanol, the RNA was solubilized in diethyl pyrocarbonate-treated RNase-free water and quantified by measuring the absorbance at $260 \mathrm{~nm}$ using a UV-1750 spectrophotometer (Shimadzu, Kyoto, Japan). Equal amounts of RNA $(1 \mu \mathrm{g})$ were reverse transcribed in a master mix containing $1 \mathrm{X}$ reverse transcriptase buffer, dNTPs $(1 \mathrm{mM})$, oligodT $_{18}$ primers (500 ng), MMLV reverse transcriptase (140 U), and RNase inhibitor (40 U) for $45 \mathrm{~min}$ at $42^{\circ} \mathrm{C}$. PCR was then performed in an automatic thermocycler (Bioneer, Daejeon, South Korea) for 40 cycles $\left(94^{\circ} \mathrm{C}\right.$ for $5 \mathrm{~min}, 58^{\circ} \mathrm{C}$ for $30 \mathrm{sec}$, and $72^{\circ} \mathrm{C}$ for $90 \mathrm{sec}$ ) followed by a $10 \mathrm{~min}$ extension at $95^{\circ} \mathrm{C}$. The primer sequences as presented at Table I. The PCR products were separated in $2 \%$ agarose gels and visualized by $\mathrm{EtBr}$ staining. GAPDH was used for normalization of the results. Gene expression was quantified using ImageJ software (version 1.44; National Institutes of Health, Bethesda, MD, USA) and results presented as fold change compared to the control group.

Statistical analysis. Data are presented as the mean \pm standard deviation. Differences between the mean values for individual groups were assessed by a one-way analysis of variance with Duncan's multiple range tests. $\mathrm{P}<0.05$ was considered to indicate a statistically significant difference. The SAS v9.1 statistical software package (SAS Institute Inc., Cary, NC, USA) was used for the statistical analysis.

\section{Results}

BLSEE reduced HCT-116 cancer cell growth. As shown in Table II, BLSEE significantly inhibited the colon cancer HCT-116 cell growth in vitro in a dose-dependent manner. At a high dose of $400 \mu \mathrm{g} / \mathrm{ml}$, BLSEE showed the highest inhibition activity of HCT-116 cells (86.3\%; $\mathrm{P}=0.0002)$, compared with doses of $100(\mathrm{P}=0.0006)$ and $200 \mu \mathrm{g} / \mathrm{ml} \mathrm{BLSEE}(\mathrm{P}=0.0017)$.

BLSEE induced the apoptosis in HCT-116 cancer cells. Flow cytometry analysis revealed that BLSEE treatment was able to promote apoptosis in HCT-116 cells. As shown in Fig. 1, 
Table I. Sequences of reverse transcription-polymerase chain reaction primers.

\begin{tabular}{|c|c|}
\hline Gene name & Sequence \\
\hline \multicolumn{2}{|l|}{ Caspase-3 } \\
\hline Forward & 5'-CAAACTTTTTCAGAGGGGATCG-3' \\
\hline Reverse & 5'-GCATACTGTTTCAGCATGGCA-3' \\
\hline \multicolumn{2}{|l|}{ Caspase- 8} \\
\hline Forward & 5'-CCCCACCCTCACTTTGCT-3' \\
\hline Reverse & 5'-GGAGGACCAGGCTCACTTA-3' \\
\hline \multicolumn{2}{|l|}{ Caspase-9 } \\
\hline Forward & 5'-GGCCCTTCCTCGCTTCATCTC-3' \\
\hline Reverse & 5'-GGTCCTTGGGCCTTCCTGGTAT-3' \\
\hline \multicolumn{2}{|l|}{ Bax } \\
\hline Forward & 5'-AAGCTGAGCGAGTGTCTCCGGCG-3' \\
\hline Reverse & 5'-CAGATGCCGGTTCAGGTACTCAGTC-3' \\
\hline \multicolumn{2}{|r|}{ ( } \\
\hline Forward & 5'-CTCGTCGCTACCGTCGTGACTTGG-3' \\
\hline Reverse & 5'-CAGATGCCGGTTCAGGTACTCAGTC-3' \\
\hline \multicolumn{2}{|l|}{ Bcl-xL } \\
\hline Forward & 5'-CCCAGAAAGGATACAGCTGG-3' \\
\hline Reverse & 5'-GCGATCCGACTCACCAATAC-3' \\
\hline \multicolumn{2}{|l|}{ TRAIL } \\
\hline Forward & 5'-GGAACC CAAGGTGGGTAGAT-3' \\
\hline Reverse & 5'-TCTCACCACACTGCAACCTC-3' \\
\hline \multicolumn{2}{|l|}{ DR4 } \\
\hline Forward & 5'-AAGTCCCTGCACCACGAC-3' \\
\hline Reverse & 5'-CCACAACCTGAGCCGATG-3' \\
\hline \multicolumn{2}{|l|}{ DR5 } \\
\hline Forward & 5'-TGAGATAAAGGTGGCTAAA-3' \\
\hline Reverse & 5'-AAAGGTAAACCAGGGAAG-3' \\
\hline \multicolumn{2}{|l|}{$\mathrm{NF}-\kappa \mathrm{B}$} \\
\hline Forward & $\begin{array}{l}\text { 5'-CACTTATGGACAACTATGAGGTCTCT } \\
\text { GG-3' }\end{array}$ \\
\hline Reverse & $\begin{array}{l}\text { 5'-CTGTCTTGTGGACAACGCAGTGGAA } \\
\text { TTTTAGG-3' }\end{array}$ \\
\hline \multicolumn{2}{|l|}{$\mathrm{I} \kappa \mathrm{B} \alpha$} \\
\hline Forward & 5'-GCTGAAGAAGGAGCGGCTACT-3' \\
\hline Reverse & 5'-TCGTACTCCTCGTCTTTCATGGA-3' \\
\hline \multicolumn{2}{|l|}{ iNOS } \\
\hline Forward & 5'-AGAGAGATCGGGTTCACA-3' \\
\hline Reverse & 5'-CACAGAACTGAGGGTACA-3' \\
\hline \multicolumn{2}{|l|}{$\mathrm{COX}-2$} \\
\hline Forward & 5'-TTAAAATGAGATTGTCCGAA-3' \\
\hline Reverse & 5'-AGATCACCTCTGCCTGAGTA-3' \\
\hline \multicolumn{2}{|l|}{ MMP-2 } \\
\hline Forward & 5'-CTTCTTCAAGGACCGGTTCA-3' \\
\hline Reverse & 5'-GCTGGCTGAGTACCAGTA-3' \\
\hline \multicolumn{2}{|l|}{ MMP-9 } \\
\hline Forward & 5'-TGGGCTACGTGACCTATGAC-3' \\
\hline Reverse & 5'-GCCCAGCCCACCTCCACTCC-3' \\
\hline \multicolumn{2}{|l|}{ TIMP-1 } \\
\hline Forward & 5'-GTCAGTGAGAAGCAAGTCGA-3' \\
\hline Reverse & 5'-ATGTTCTTCTCTGTGACCCA-3' \\
\hline
\end{tabular}

Table I. Continued.

\begin{tabular}{lc}
\hline Gene name & Sequence \\
\hline TIMP-2 & \\
Forward & 5'-TGGGGACACCAGAAGTCAAC-3' \\
Reverse & 5'-TTTTCAGAGCCTTGGAGGAG-3' \\
Fas & \\
Forward & 5'-GAAATGAAATCCAAAGCT-3' \\
Reverse & 5'-TAATTTAGAGGCAAAGTGGC-3' \\
FasL & \\
Forward & 5'-GGATTGGGCCTGGGGATGTTTCA-3' \\
Reverse & 5'-TTGTGGCTCAGGGGCAGGTTGTTG-3' \\
GAPDH & \\
Forward & 5'-CGGAGTCAACGGATTTGGTC-3' \\
Reverse & 5'-AGCCTTCTCCATGGTCGTGA-3' \\
\hline
\end{tabular}

Bcl-2, B-cell lymphoma-2; Bax, Bcl-2-associated $\mathrm{X}$ protein; Bcl-xL, Bcl-extra large; TRAIL, tumor necrosis factor-related apoptosis-inducing ligand; DR4, death receptor 4; DR5, death receptor 5; $\mathrm{NF}-\kappa \mathrm{B}$, nuclear factor- $\kappa \mathrm{B}$; I $\kappa \mathrm{B} \alpha$, inhibitory $\kappa \mathrm{B} \alpha$; iNOS, inducible nitric oxide synthase; COX-2, cyclooxygenase 2; MMP-2, matrix metalloproteinase-2; MMP-9, matrix metalloproteinase-9; TIMP-1, TIMP metallopeptidase inhibitor 1; TIMP-2, TIMP metallopeptidase inhibitor 2; FasL, Fas ligand.

the BLSEE treatment significantly increased the proportion of apoptotic cells to $10.2(\mathrm{P}=0.0043), 19.7(\mathrm{P}=0.0032)$ and $41.3 \%$ $(\mathrm{P}=0.0020)$ compared with the non-treated cells $(2.3 \%)$.

Effect of BLSEE on the expression of Fas, FasL, tumor necrosis factor (TNF)-related apoptosis-inducing ligand (TRAIL), death receptor 4 (DR4) and death receptor 5 (DR5) in HCT-116 cells. Following treatment with various doses of BLSEE, the mRNA levels of Fas ( $\mathrm{P}=0.0019$ at $400 \mu \mathrm{g} / \mathrm{ml})$ and FasL $(\mathrm{P}=0.0003$ at $400 \mu \mathrm{g} / \mathrm{ml})$ were upregulated in HCT-116 cells (Fig. 2). In addition, $400 \mu \mathrm{g} / \mathrm{ml}$ of BLSEE significantly upregulated the mRNA levels of TRAIL (24.7-fold; $\mathrm{P}=0.0015$ ), DR4 (133.2-fold; $\mathrm{P}=0.0027$ ) and DR5 (7.5-fold; $\mathrm{P}=0.0064)$ compared with non-treated HCT-116 cells (Fig. 3).

Effect of BLSEE on the expression of caspases 3, 8 and 9 in HCT-116 cells. The effect of BLSEE on the mRNA caspase family, including caspases 3, 8 and 9 in HCT-116 colon cancer cells was determined by RT-PCR assay. BLSEE treatment significantly increased the $\mathrm{mRNA}$ expressions of these caspases in HCT-116 cells in a dose-dependent manner (Fig. 4). The highest dose $(400 \mu \mathrm{g} / \mathrm{ml})$ of BLSEE also increased the mRNA levels of caspase-3 (10.9-fold; $\mathrm{P}=0.0001)$, caspase-8 (3.5-fold; $\mathrm{P}=0.0046)$ and caspase-9 $(11.9$-fold; $\mathrm{P}=0.0014)$ compared to the non-treated HCT-116 cells.

BLSEE modulated the expressions of Bcl-2, Bcl-xL and Bax in HCT-116 cells. As shown in Fig. 5, BLSEE treatment dose-dependently reduced the expression of $\mathrm{Bcl}-2$ and $\mathrm{Bcl}-\mathrm{xL}$ in HCT-116 cells. At the highest dose of $400 \mu \mathrm{g} / \mathrm{ml}$, BLSEE significantly reduced the mRNA levels of Bcl-2 $(98.9 \%$; $\mathrm{P}=0.0009)$ and $\mathrm{Bcl}-\mathrm{xL}(96.3 \% ; \mathrm{P}=0.0006)$ compared to the 
Table II. Growth inhibition of human HCT-116 colon cancer cells by Ba lotus stamen extract as evaluated by MTT assay.

\begin{tabular}{lccr}
\hline Treatment $(\mu \mathrm{g} / \mathrm{ml})$ & $\mathrm{OD}_{540}$ & Inhibitory rate, $\%$ & $\mathrm{P}$-value \\
\hline Control & $0.488 \pm 0.003$ & & $0.0017^{\mathrm{a}}$ \\
$100 \mu \mathrm{g} / \mathrm{ml} \mathrm{BLSEE}$ & $0.373 \pm 0.008$ & $23.6 \pm 0.4$ & $0.0006^{\mathrm{a}}$ \\
$200 \mu \mathrm{g} / \mathrm{ml} \mathrm{BLSEE}$ & $0.238 \pm 0.010$ & $51.2 \pm 0.5$ & $0.0002^{\mathrm{a}}$ \\
$400 \mu \mathrm{g} / \mathrm{ml} \mathrm{BLSEE}$ & $0.067 \pm 0.002$ & $86.3 \pm 0.4$ &
\end{tabular}

${ }^{a} \mathrm{P}<0.01$ vs. the control group. $\mathrm{OD}_{540}$, optical density at $540 \mathrm{~nm}$; BLSSEE, Ba lotus stamen extract.

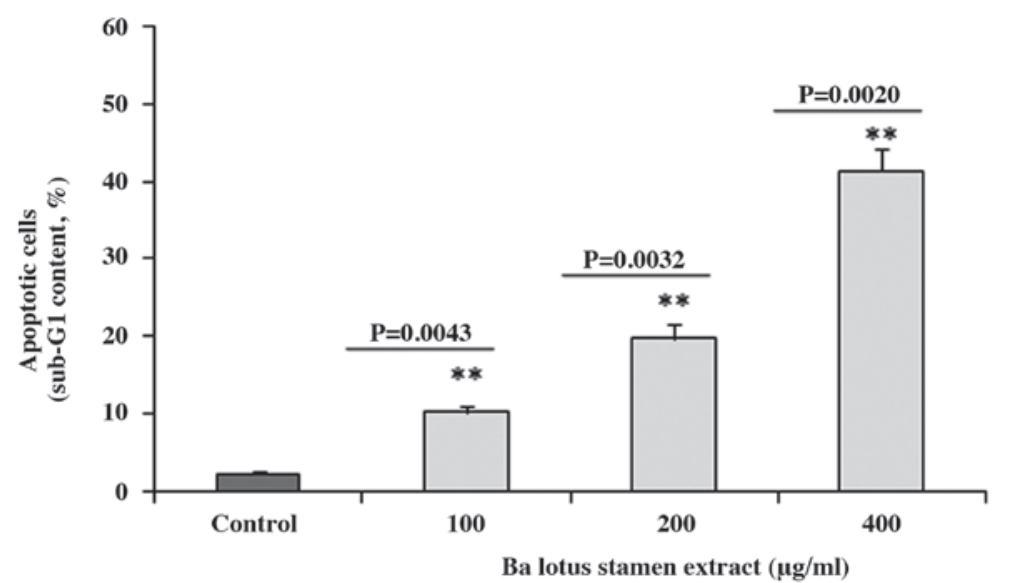

Figure 1. Level of apoptosis (sub-G1 content) induced by Ba lotus stamen extract in HCT-116 human colon cancer cells was evaluated using flow cytometry. ${ }^{* *} \mathrm{P}<0.01$ vs. the control group. Ba lotus, Nelumbo nucifera.
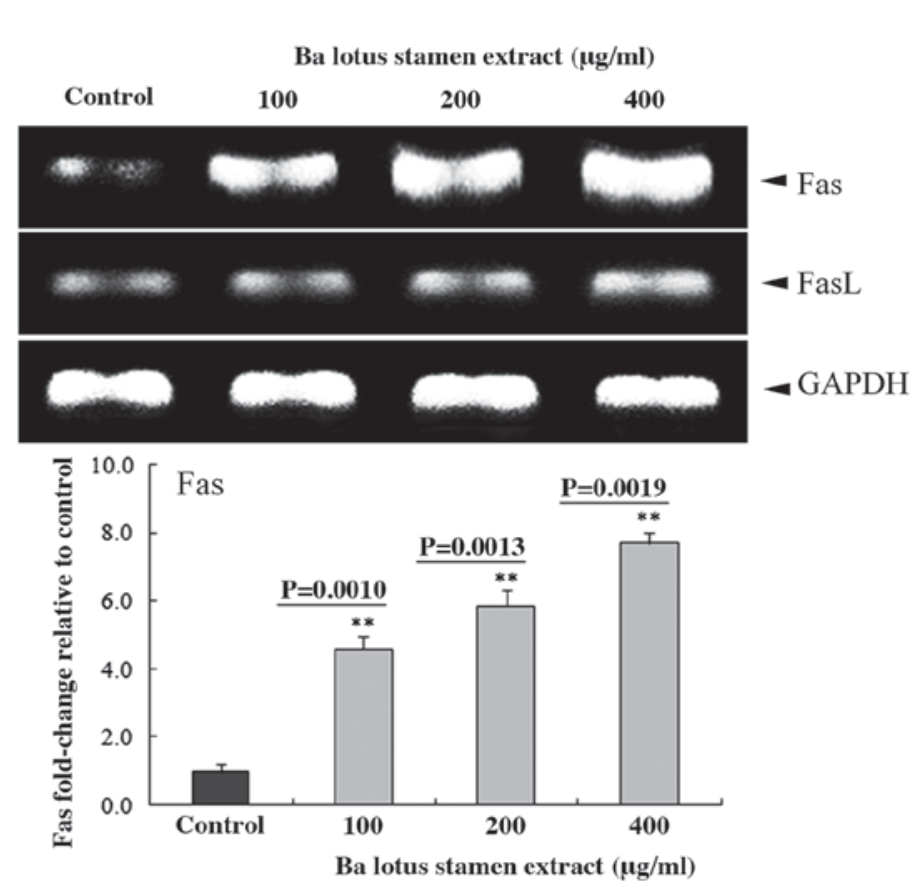
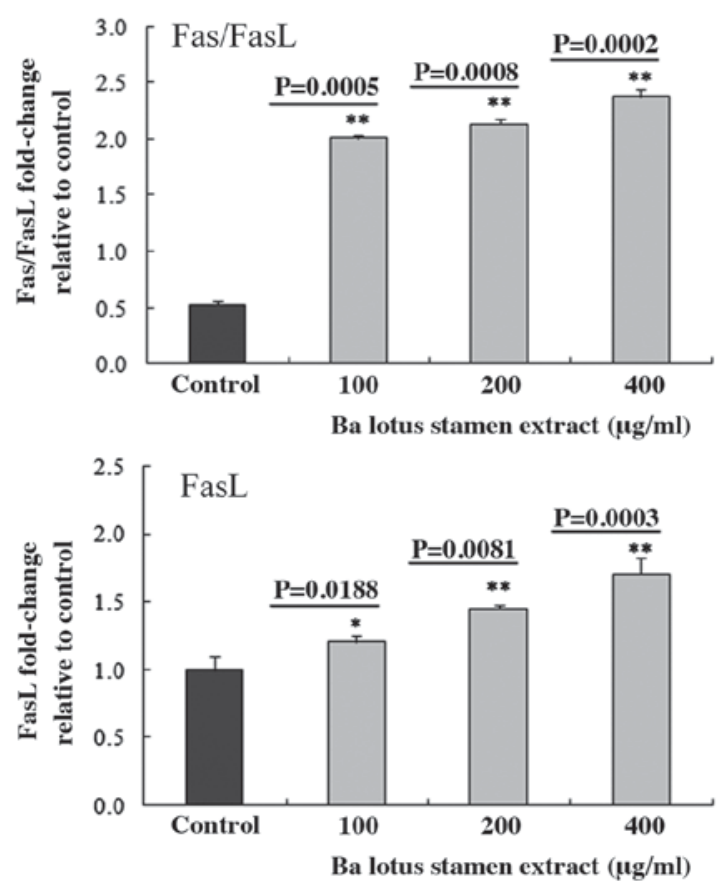

Figure 2. Effect of Ba lotus stamen extract on the mRNA expression of Fas/FasL, Fas and FasL in human colon cancer HCT-116 cells. The fold-ratio was calculated as follows: Gene expression/GAPDH x control numerical value (control fold ratio, 1$)$. ${ }^{*} \mathrm{P}<0.05,{ }^{* *} \mathrm{P}<0.01$ vs. the control group. FasL, Fas ligand; Ba lotus, Nelumbo nucifera.

non-treated HCT-116 cells, respectively. By contrast, $400 \mu \mathrm{g} / \mathrm{ml}$ of BLSEE also enhanced the Bax levels of mRNA (2.9-fold; $\mathrm{P}=0.0036$ ) compared to non-treated HCT-116 cells.
BLSEE modulated the expression of matrix metalloproteinase (MMP)-2, MMP-9, TIMP metallopeptidase inhibitor 1 (TIMP-1) and TIMP metallopeptidase inhibitor 2 (TIMP-2) 

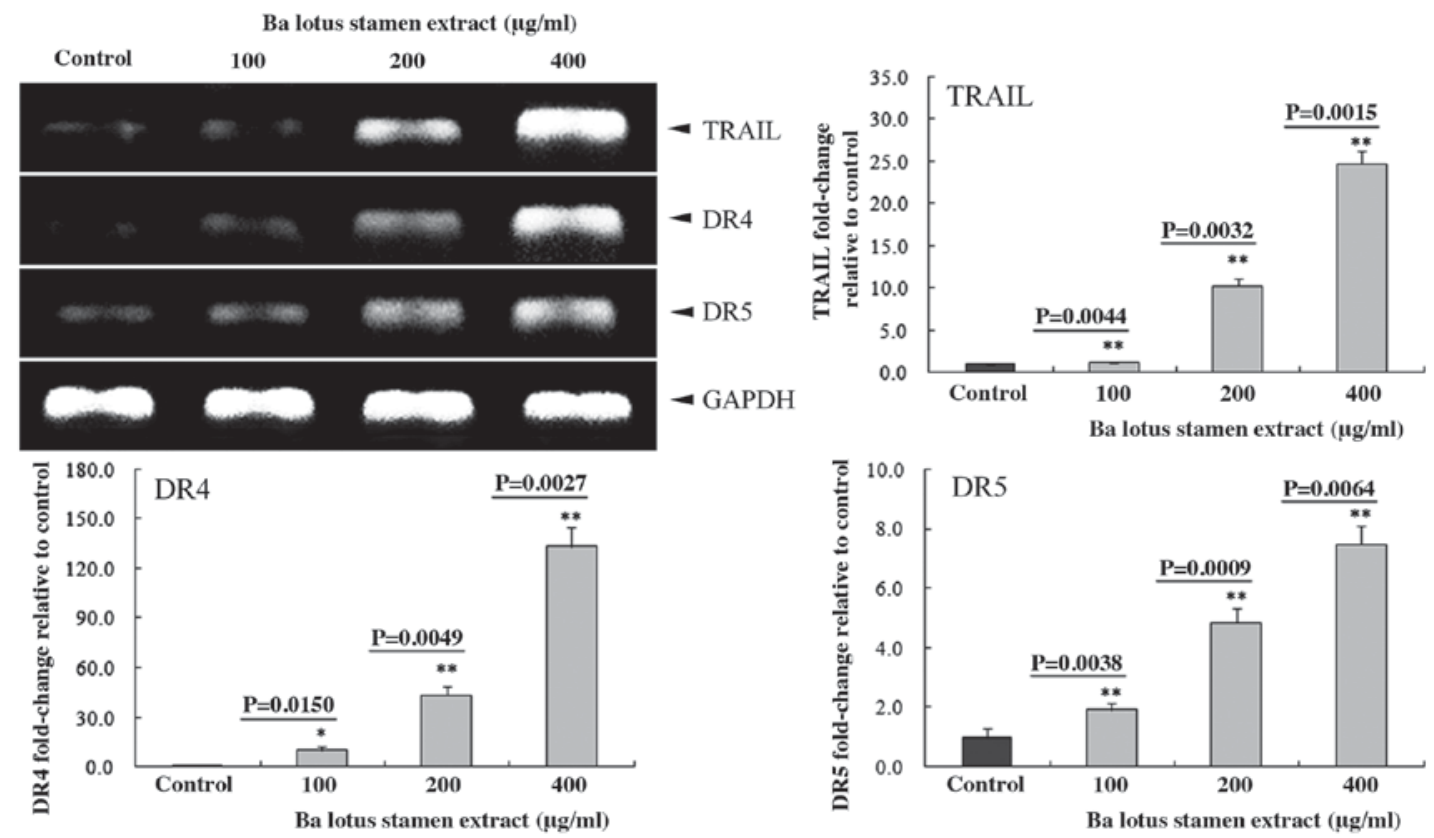

Figure 3. Effect of Ba lotus stamen extract on the mRNA expression of TRAIL, DR4 and DR5 in human colon cancer HCT-116 cells. The fold-ratio was calculated as follows: Gene expression/GAPDH x control numerical value (control fold ratio, 1 ). ${ }^{*} \mathrm{P}<0.05,{ }^{* *} \mathrm{P}<0.01$ vs. the control group. TRAIL, tumor necrosis factor-related apoptosis-inducing ligand; DR4, death receptor 4; DR5, death receptor 5. Ba lotus, Nelumbo nucifera.
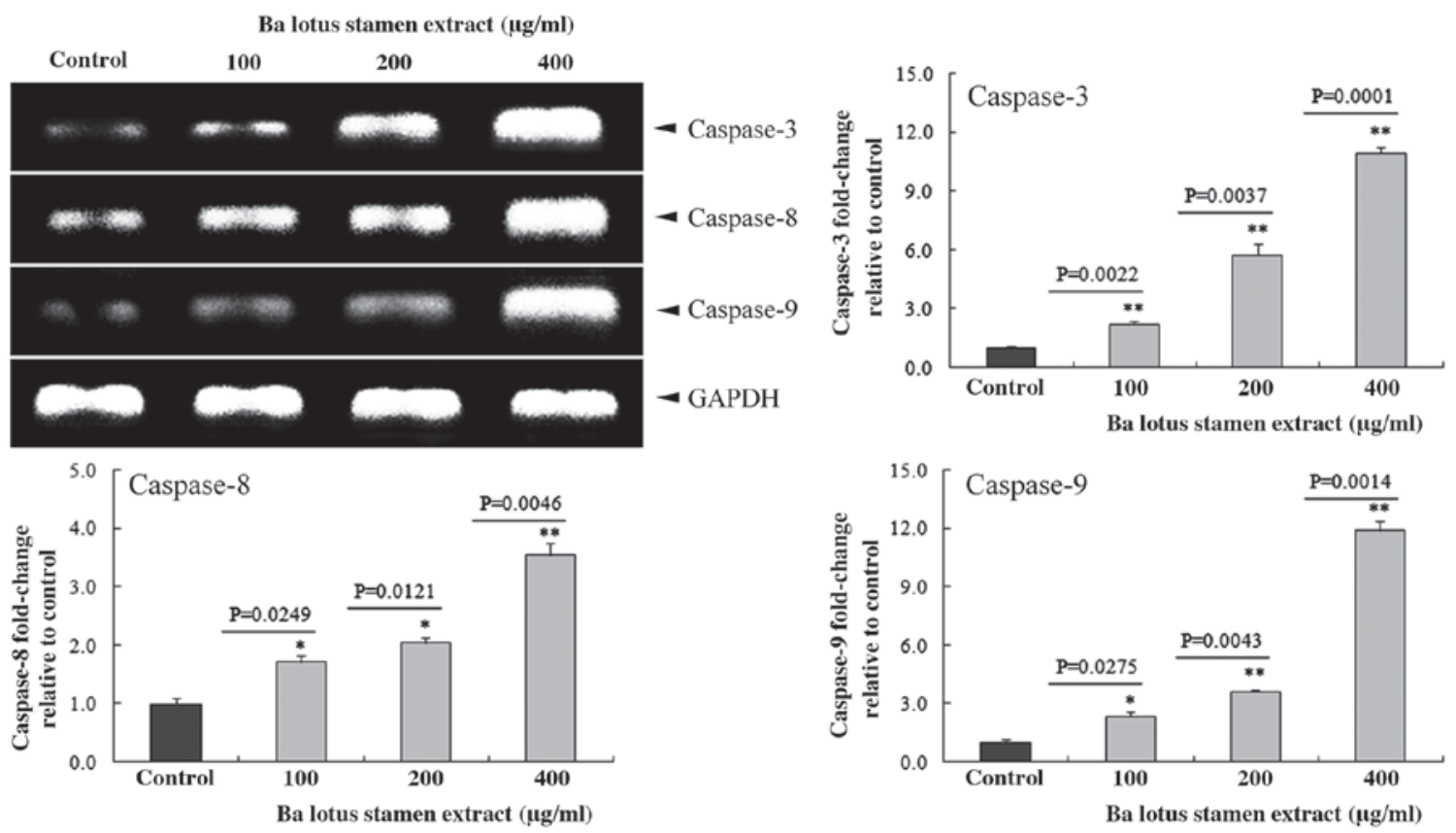

Figure 4. Effect of Ba lotus stamen extract on the mRNA expression of caspase-3, caspase- 8 and caspase-9 in human colon cancer HCT-116 cells. The fold-ratio was calculated as follows: Gene expression/GAPDH x control numerical value (control fold ratio, 1$) .{ }^{*} \mathrm{P}<0.05,{ }^{* *} \mathrm{P}<0.01$ vs. the control group. Ba lotus, Nelumbo nucifera.

in HCT-116 cells. As shown in Fig. 6, BLSEE treatment dose-dependently reduced the expression of MMP-2 and MMP-9 in HCT-116 cells. At the highest dose of $400 \mu \mathrm{g} / \mathrm{ml}$, BLSEE significantly reduced the mRNA levels of MMP-2 (95.8\%; $\mathrm{P}=0.0002)$ and MMP-9 (85.9\%; $\mathrm{P}=0.0002)$ compared with non-treated HCT-116 cells. By contrast, $400 \mu \mathrm{g} / \mathrm{ml}$ of BLSEE was also able to enhance the mRNA levels of TIMP-1 (17.6-fold; $\mathrm{P}=0.0004$ ) and TIMP-2 (73.6-fold; $\mathrm{P}=0.0002)$ compared with non-treated HCT-116 cells.
BLSEE modulated the expression of inducible nitric oxide synthase (iNOS), cyclooxygenase 2 (COX-2), nuclear factor $(N F)-\kappa B$ and inhibitory $\kappa B \alpha(I \kappa B \alpha)$ in HCT-116 cells. BLSEE treatment significantly decreased the mRNA levels of iNOS, COX -2 and NF- $\kappa \mathrm{B}$, and increased the $\mathrm{I} \kappa \mathrm{B} \alpha$ levels in HCT-116 cells (Fig. 7). Subsequent to treatment with a dose of $400 \mu \mathrm{g} / \mathrm{ml}$ BLSEE, the mRNA levels of iNOS, COX-2 and NF- $\kappa \mathrm{B}$ were decreased by $89.2(\mathrm{P}=0.0008), 88.3(\mathrm{P}=0.0002)$ and $87.9 \%$ $(\mathrm{P}=0.0007)$ compared with the non-treated HCT-116 cells. 

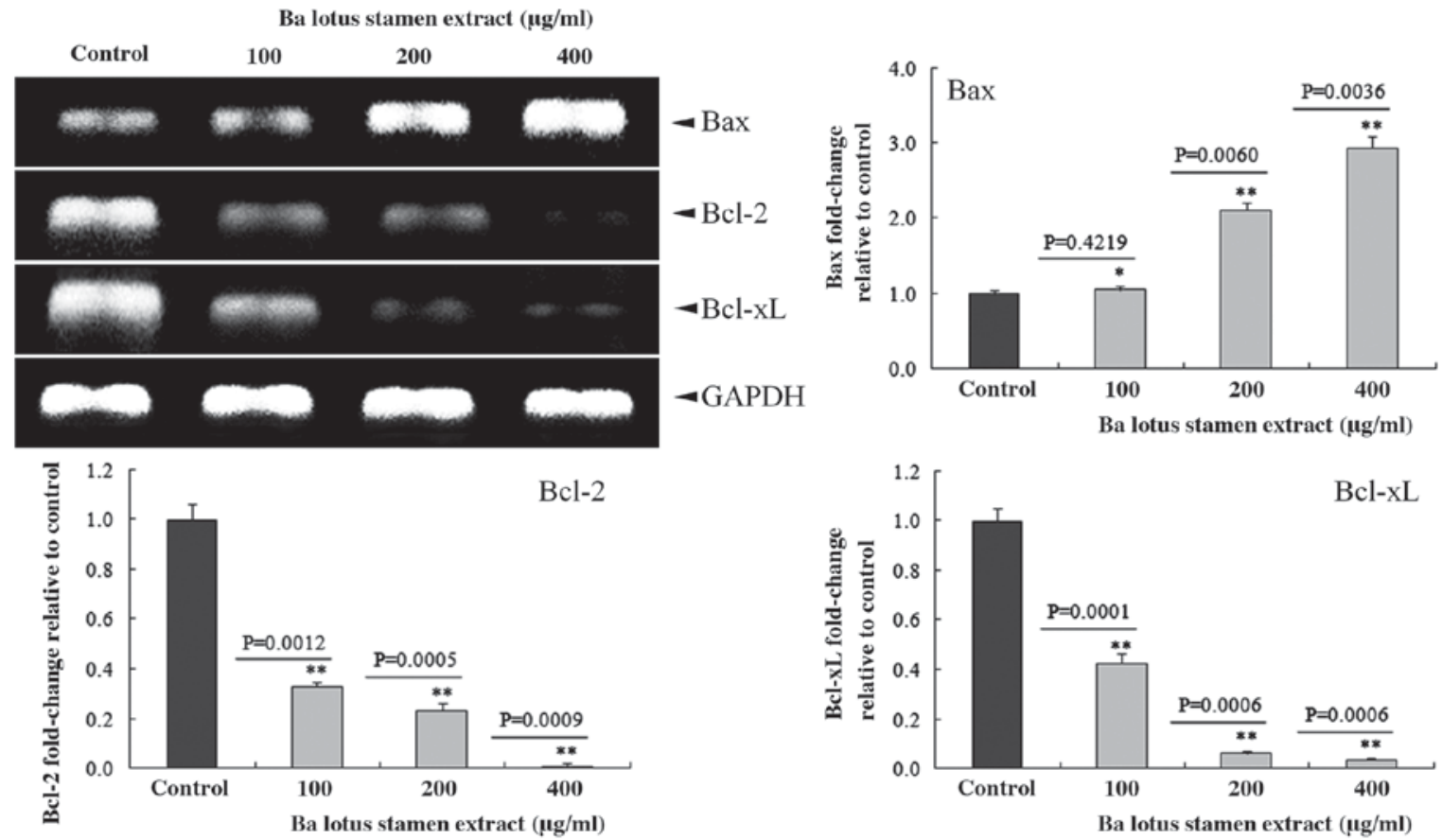

Figure 5. The effects of Ba lotus stamen extract on the mRNA expression of Bax, Bcl-2 and Bcl-xL in human colon cancer HCT-116 cells. The fold-ratio was calculated as follows: Gene expression/GAPDH x control numerical value (control fold ratio, 1). ${ }^{*} \mathrm{P}<0.05,{ }^{* *} \mathrm{P}<0.01$ vs. the control group. Bcl-2, B-cell lymphoma-2; Bax, Bcl-2-associated X protein; Bcl-xL, Bcl-extra large; Ba lotus, Nelumbo nucifera.
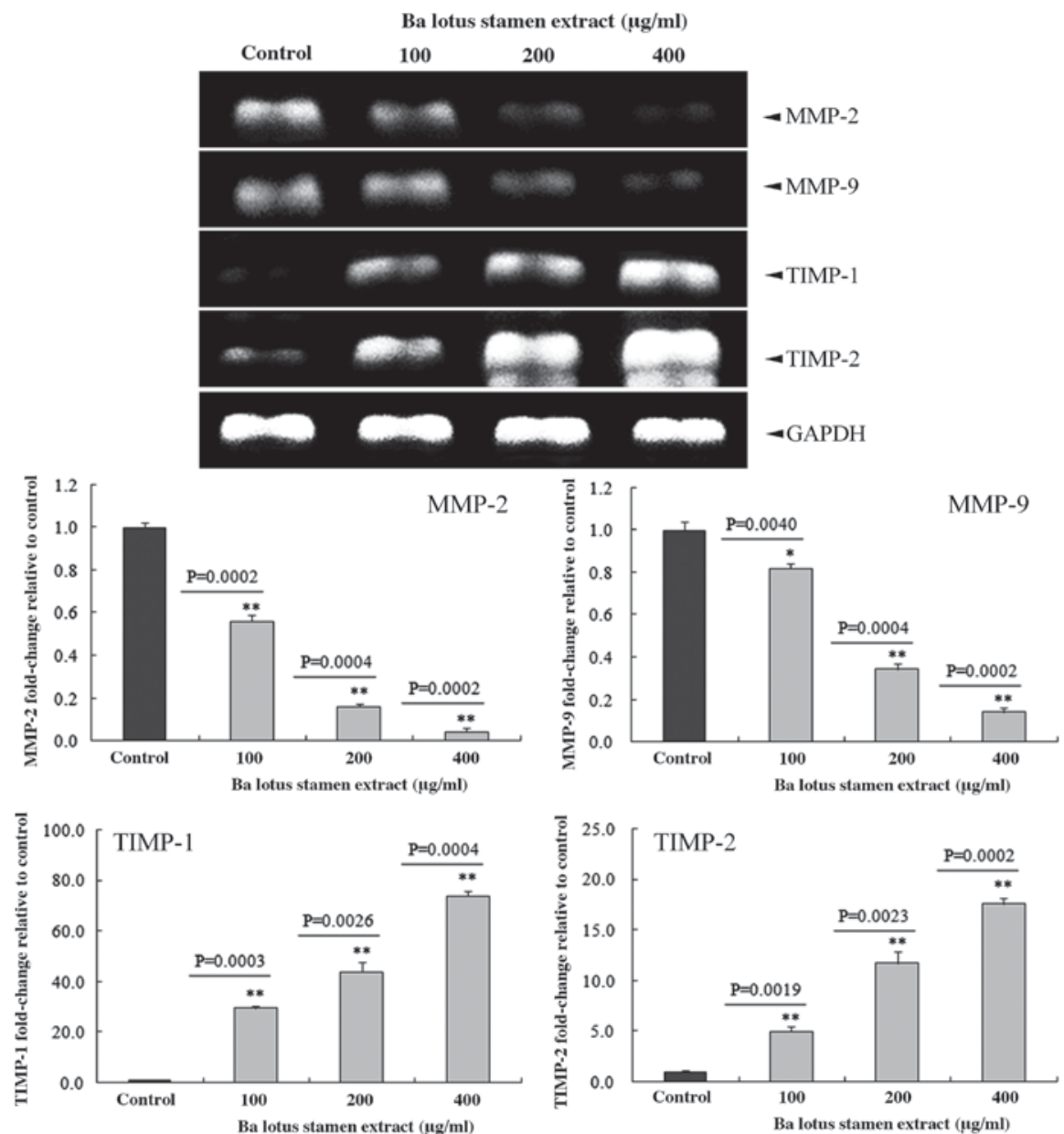

Figure 6. The effects of Ba lotus stamen extract on the mRNA expression of MMP-2, MMP-9, TIMP-1 and TIMP-2 in human colon cancer HCT-116 cells. The fold-ratio was calculated as follows: Gene expression/GAPDH x control numerical value (control fold ratio, 1). "P $<0.05,{ }^{* *} \mathrm{P}<0.01$ vs. the control group. MMP-2, matrix metalloproteinase-2; MMP-9, matrix metalloproteinase-9; TIMP-1, TIMP metallopeptidase inhibitor 1; TIMP-2, TIMP metallopeptidase inhibitor 2; Ba lotus, Nelumbo nucifera. 


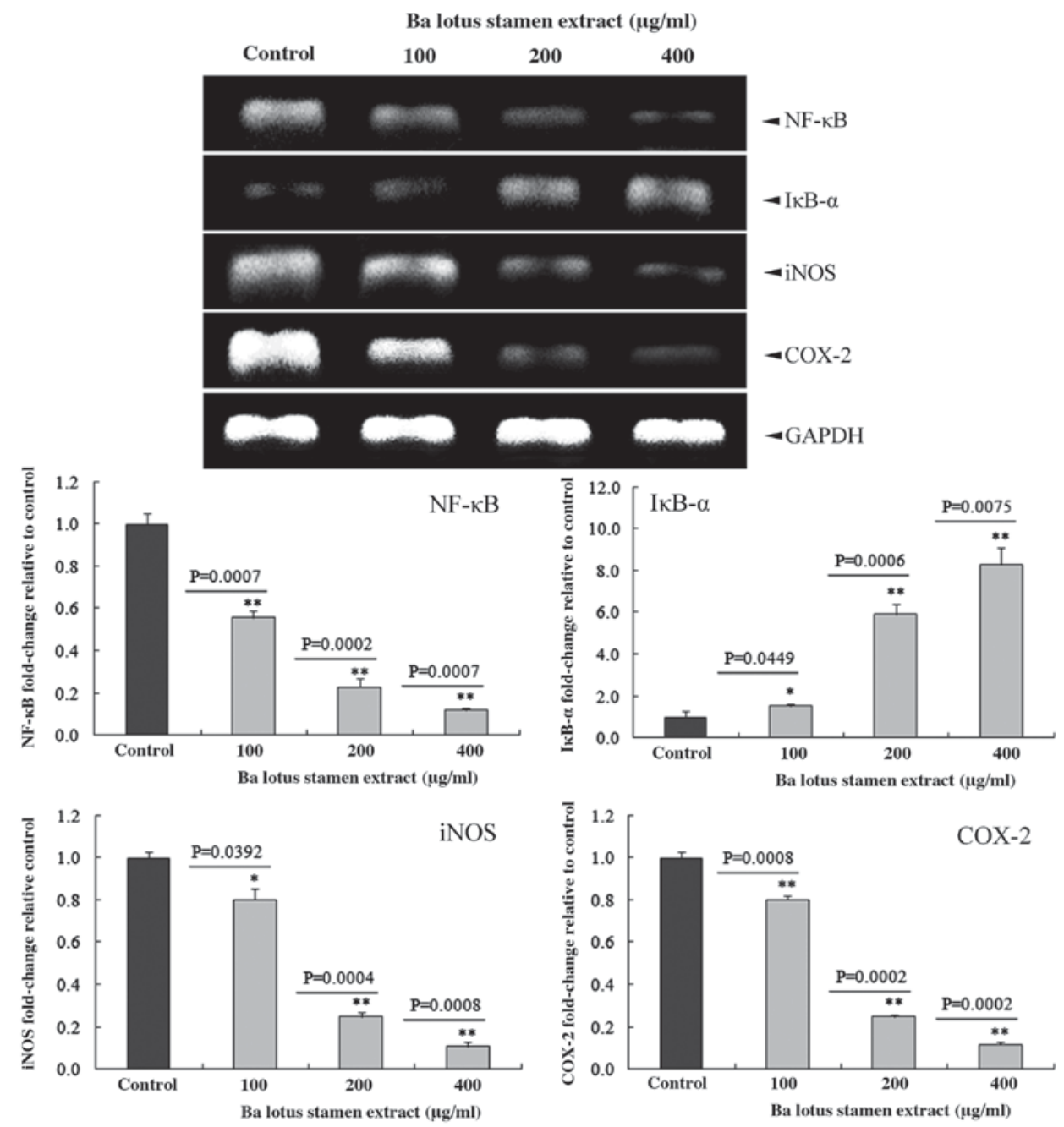

Figure 7. The effects of Ba lotus stamen extract on the mRNA expression of NF-кB, IкB $\alpha$, iNOS and COX-2 in human colon cancer HCT-116 cells. The fold-ratio was calculated as follows: Gene expression/GAPDH x control numerical value (control fold ratio, 1). ${ }^{*} \mathrm{P}<0.05,{ }^{* * *} \mathrm{P}<0.01$ vs. the control group. NF-kB,

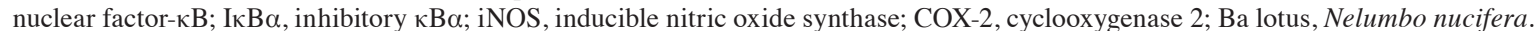

In addition, BLSEE also increased the mRNA levels of $\mathrm{I} \kappa \mathrm{B} \alpha$ (8.3-fold; $\mathrm{P}=0.0075$ ) compared with non-treated HCT-116 cells.

\section{Discussion}

In the present study, BLSEE treatment was found to significantly inhibit the cell proliferation, and also increase the proportion of cells in the sub-G1 phase in HCT-116 cancer cells. These results suggested that BLSEE may induce apoptosis in HCT-116 cells.

Based on these observations, the mRNA expression of apoptosis-associated death receptors, including Fas and FasL, was analyzed in HCT-116 cells using an RT-PCR assay. Fas and FasL are apoptosis inducers, and play an important role during death receptor-induced extrinsic apoptosis in cells (25). The present study found that following incubation with $24 \mathrm{~h}$ of BLSEE, the mRNA levels of Fas and FasL were each significantly increased in HCT-116 cells. Activation of Fas/FasL was able to recruit FADD and death domain, and subsequently induce the activation of caspases 8,9 and 10 to promote cellular apoptosis (26). In addition, the present study also observed that mRNA levels of TRAIL, DR4 and DR5 were increased by BLSEE treatment for $24 \mathrm{~h}$.
TRAIL binds to TRAIL receptors, such as DR4 and DR5, to form a trimeric complex, which leads to the recruitment of FADD, an adaptor molecule that recruits and activates caspase-8 $(27,28)$.

The caspase signaling cascade is a key event in extrinsic and intrinsic cell apoptosis, which is characterized by the activation of caspase- 8 and caspase-9, respectively (9). Caspase- 8 is a main initiator caspase in Fas signaling, and is recruited to the activated Fas receptor, as well as inducing death receptor-induced cell apoptosis (29). In addition, caspase-9 is an apoptosis effector molecule in the mitochondrial channel and starts programmed cell death subsequent to activation (10). Activated caspase- 8 and caspase- 9 are each able to activate caspase-3, which is an executor of apoptosis that subsequently induces apoptosis in cells (8). In the present study, it was found that the mRNA levels of caspases 3,8 and 9 were significantly increased in BLSEE-treated HCT-116 cells.

It was also found that BLSEE treatment was able to modulate the mRNA expression of apoptosis-associated Bcl-2 family members in HCT-116 cells. BLSEE treatment significantly reduced the mRNA levels of anti-apoptotic Bcl-2 and Bcl-xL in HCT-116 cells. Bcl-2 and Bcl-xL are generally known as factors that prevent the release of Cyto $c$ 
from the mitochondria into the cytosol, inhibiting apoptosis and promoting the survival of cells (5). Bcl-xL can also block the formation of the apoptosome, which converges with Cyto $c$, Apaf-1 and procaspase-9, to reduce the activation of caspase- 3 and inhibit apoptosis $(30,31)$. The balance between anti-apoptosis and pro-apoptosis factors may affect the occurrence of apoptosis in cells, and is also associated with the success or failure of chemotherapy in cancer patients (32). By contrast, BLSEE was able to increase the mRNA levels of Bax, which is a pro-apoptotic protein, to promote apoptosis in cells $(5,7)$. The activated Bax may be directly engaged by Bim to promote apoptosis in cells (33). In addition, Bax also induces the activation of caspase- 8 and the release of Cyto $c$ from the mitochondria, resulting in the cleavage of caspase- 9 , and contributes to the activation of executor caspase- $3(5,34)$. The present results suggest that the BLSEE may modulate the balance between anti-apoptosis and pro-apoptosis factors, in particular enhancing the expression levels of pro-apoptotic Bax to promote apoptosis in HCT-116 cells.

MMPs are an important family of proteolytic enzymes that not only contribute to organ development and tissue regeneration, but also show an extremely important role in the regulation of tumor invasion, angiogenesis and metastasis $(35,36)$. In particular, MMP-2 exhibits a key role in the progression of colon cancer and the promotion of metastasis (37). Additionally, overexpression of MMP-9 is closely associated with poor prognosis in patients with colon cancer (38). Numerous studies have reported that herbs extracts were able to inhibit the migration or invasion of colorectal cancer cells by downregulating MMP-2 and MMP-9 in vivo (39-41). In the present study, it was found that BLSEE significantly reduced the expression of MMP-2 and MMP-9, and also increased the activation of TIMP-1 and TIMP-2 in HCT-116 colon cancer cells. As natural MMP inhibitors, TIMP-1 and TIMP-2 are able to inhibit the activation of MMP-2 and MMP-9 to reduce the invasion and metastasis in patients with colon cancer $(42,43)$. Subsequent to treatment with BLSEE, the expression levels of TIMP-1 and TIMP-2 were significantly increased. Furthermore, maintaining an increased level of TIMP-1 and TIMP-2 may improve the poor survival of CRC patients $(37,44)$.

Over activation of $\mathrm{NF}-\kappa \mathrm{B}$ has been found in numerous human cancers $(45,46)$. NF- $\kappa \mathrm{B}$ promotes cell proliferation, negatively regulates cell apoptosis (47), reduces cell death in tumorigenesis (48) and induces the inflammatory reaction in human disease $(46,49)$. The activation of $N F-\kappa B$ is able to reduce TNF- $\alpha$-induced cell apoptosis (50). TNF- $\alpha$ directly activates the apoptosis inhibitor Bcl-xL (51), and suppresses anti-apoptosis factors, including inhibitor of apoptosis, caspase 8-FADD-like IL-1b-converting enzyme inhibitory protein, TNF receptor associated factor (TRAF) 1 and TRAF2 to regulate the pro- or anti-apoptotic pathways (52). In the present study, BLSEE treatment significantly reduced the mRNA levels of NF- $\kappa \mathrm{B}$, and also increased the mRNA levels of I $\kappa \mathrm{B} \alpha$ in HCT-116 cells. Enhancement of the I $\mathrm{B} \mathrm{B} \alpha$ activation is a potential strategy to reduce cancer cell growth in clinical chemotherapy $(53,54)$.

In conclusion, the present study has clearly indicated that BLSEE suppresses the proliferation of human HCT-116 colon carcinoma cells in vitro. BLSEE may effectively induce the apoptosis through reducing the ratio of anti-apoptotic $\mathrm{Bcl}-2$ to pro-apoptotic Bax, and increasing the activation of the death receptor system, as well as promoting the cleavage of caspases-3, 8 and 9 in HCT-116 cells. These results suggest that the BLSEE is able to induce HCT-116 cell apoptosis through activating death receptor and mitochondrial apoptotic pathways.

\section{Acknowledgements}

The present study was supported by Chongqing Engineering Research Center for Functional Food (grant no., cstc2015yfpt_ gcjsyjzx0027) and the Program for Innovation and Team Building at the Chongqing Institute of Higher Education (grant no. CXTDX201601040).

\section{References}

1. Siegel R, Ma J, Zou Z and Jemal A: Cancer statistics, 2014. CA Cancer J Clin 64: 9-29, 2014.

2. Long N, Moore M, Chen W, Gao CM, Lai MS, Mizoue T, Oyunchimeg D, Park S, Shin HR, Tajima K, et al: Cancer epidemiology and control in north-East Asia-past, present and future. Asian Pac J Cancer Prev 11 (Suppl 2): S107-S148, 2010.

3. Wang ZX, Cao JX, Liu ZP, Cui YX, Li CY, Li D, Zhang XY, Liu JL and Li JL: Combination of chemotherapy and immunotherapy for colon cancer in China: A meta-analysis. World J Gastroenterol 20: 1095-1060, 2014.

4. Wong RS: Apoptosis in cancer: From pathogenesis to treatment. J Exp Clin Cancer Res 30: 87, 2011.

5. Ola MS, Nawaz M and Ahsan H: Role of Bcl-2 family proteins and caspases in the regulation of apoptosis. Mol Cell Biochem 351: $41-58,2011$

6. Volkmann N, Marassi FM, Newmeyer DD and Hanein D: The rheostat in the membrane: BCL-2 family proteins and apoptosis. Cell Death Differ: 206-215, 2014.

7. Peter ME and Krammer PH: The CD95(APO-1/Fas) DISC and beyond. Cell Death Differ 10: 26-35, 2003.

8. Martinou JC and Youle RJ: Mitochondria in apoptosis: Bcl-2 family members and mitochondrial dynamics. Dev Cell 21: 92-101, 2011.

9. Cullen SP and Martin SJ: Caspase activation pathways: Some recent progress. Cell Death Differ 16: 935-938, 2009.

10. Zhao Y, Lei M, Wang Z, Qiao G, Yang T and Zhang J: TCR-induced, PKC- $\theta$-mediated NF- $\kappa \mathrm{B}$ activation is regulated by a caspase- 8 -caspase- 9 -caspase- 3 cascade. Biochem Biophys Res Commun 450: 526-531, 2014.

11. Gordaliza M: Natural products as leads to anticancer drugs. Clin Transl Oncol 9: 767-776, 2007.

12. Hsiao WL and Liu L: The role of traditional Chinese herbal medicines in cancer therapy-from TCM theory to mechanistic insights. Planta Med 76: 1118-1131, 2010.

13. Qi F, Li A, Inagaki Y, Gao J, Li J, Kokudo N, Li XK and Tang W: Chinese herbal medicines as adjuvant treatment during chemo-or radio-therapy for cancer. Biosci Trends 4: 297-307, 2010.

14. Parsons ME and Keeling DJ: Novel approaches to the pharmacological blockade of gastric acid secretion. Expert Opin Investig Drugs 14: 411-421, 2005.

15. Talukder MJ and Nessa J: Effect of Nelumbo nucifera rhizome extract on the gastrointestinal tract of rat. Bangladesh Med Res Counc Bull 24: 6-9, 1998.

16. Kuo YC, Lin YL, Liu CP and Tsai WJ: Herpes simplex virus type 1 propagation in HeLa cells interrupted by Nelumbo nucifera. J Biomed Sci 12: 1021-1034, 2005.

17. Ono Y, Hattori E, Fukaya Y, Imai S and Ohizumi Y: Anti-obesity effect of Nelumbo nucifera leaves extract in mice and rats. J Ethnopharmacol 106: 238-244, 2006.

18. Lin HY, Kuo YH, Lin YL and Chiang W: Antioxidative effect and active components from leaves of Lotus (Nelumbo nucifera). J Agric Food Chem 57: 6623-6629, 2009.

19. Wu CH, Yang MY, Chan KC, Chung PJ, Ou TT and Wang CJ: Improvement in high-fat diet-induced obesity and body fat accumulation by a Nelumbo nucifera leaf flavonoid-rich extract in mice. J Agric Food Chem 58: 7075-7081, 2010. 
20. Du H, You JS, Zhao X, Park JY, Kim SH and Chang KJ: Antiobesity and hypolipidemic effects of lotus leaf hot water extract with taurine supplementation in rats fed a high fat diet. J Biomed Sci 17 (Suppl 1): S42, 2010.

21. Lee JS, Shukla S, Kim JA and Kim M: Anti-angiogenic effect of Nelumbo nucifera leaf extracts in human umbilical vein endothelial cells with antioxidant potential. PLoS One 10: e0118552, 2015.

22. Sohn DH, Kim YC, Oh SH, Park EJ, Li X and Lee BH: Hepatoprotective and free radical scavenging effects of Nelumbo nucifera. Phytomedicine 10: 165-169, 2003.

23. Liu CP, Tsai WJ, Lin YL, Liao JF, Chen CF and Kuo YC: The extracts from Nelumbo Nucifera suppress cell cycle progression, cytokine genes expression, and cell proliferation in human peripheral blood mononuclear cells. Life Sci 75 699-716, 2004.

24. Huang CF, Chen YW, Yang CY, Lin HY, Way TD, Chiang W and Liu SH: Extract of lotus leaf (Nelumbo nucifera) and its active constituent catechin with insulin secretagogue activity. J Agric Food Chem 59: 1087-1094, 2011.

25. O'Reilly LA, Tai L, Lee L, Kruse EA, Grabow S, Fairlie WD, Haynes NM, Tarlinton DM, Zhang JG, Belz GT, et al: Membrane-bound Fas ligand only is essential for Fas-induced apoptosis. Nature 461: 659-663, 2009.

26. Waring P and Müllbacher A: Cell death induced by the Fas/Fas ligand pathway and its role in pathology. Immunol Cell Biol 77: 312-317, 1999.

27. Wang S and El-Deiry WS: TRAIL and apoptosis induction by TNF-family death receptors. Oncogene 22: 8628-8633, 2003.

28. Zhang L and Fang B: Mechanisms of resistance to TRAIL-induced apoptosis in cancer. Cancer Gene Ther 12: 228-237, 2005

29. Scaffidi C, Medema JP, Krammer PH and Peter ME: FLICE is predominantly expressed as two functionally active isoforms, caspase-8/a and caspase-8/b. J Biol Chem 272: 26953-26958, 1997.

30. Pan G, O'Rourke K and Dixit VM: Caspase-9, Bcl-XL, and Apaf-1 form a ternary complex. J Biol Chem 273: 5841-5845, 1998.

31. Hu Y, Benedict MA, Wu D, Inohara N and Núñez G: Bcl-XL interacts with Apaf-1 and inhibits Apaf-1-dependent caspase-9 activation. Proc Natl Acad Sci USA 95: 4386-4391, 1998.

32. Czabotar PE, Lessene G, Strasser A and Adams JM: Control of apoptosis by the BCL-2 protein family: Implications for physiology and therapy. Nat Rev Mol Cell Biol 15: 49-63, 2014.

33. Letai A, Bassik MC, Walensky LD, Sorcinelli MD, Weiler S and Korsmeyer SJ: Distinct BH3 domains either sensitize or activate mitochondrial apoptosis, serving as prototype cancer therapeutics. Cancer Cell 2: 183-192, 2002.

34. Finucane DM, Bossy-Wetzel E, Waterhouse NJ, Cotter TG and Green DR: Bax-induced caspase activation and apoptosis via cytochrome $c$ release from mitochondria is inhibitable by Bcl-xL. J Biol Chem 274: 2225-2233, 1999.

35. Shuman Moss LA, Jensen-Taubman S and Stetler-Stevenson WG: Matrix metalloproteinases: Changing roles in tumor progression and metastasis. Am J Pathol 181: 1895-1899, 2012

36. Gialeli C, Theocharis AD and Karamanos NK: Roles of matrix metalloproteinases in cancer progression and their pharmacological targeting. FEBS J 278: 16-27, 2011.
37. Groblewska M, Mroczko B, Gryko M, Pryczynicz A, Guzińska-Ustymowicz K, Kędra B,Kemona A and Szmitkowski M: Serum levels and tissue expression of matrix metalloproteinase 2 (MMP-2) and tissue inhibitor of metalloproteinases 2 (TIMP-2) in colorectal cancer patients. Tumour Biol 35: 3793-3802, 2014.

38. Yang B, Tang F, Zhang B, Zhao Y, Feng J and Rao Z: Matrix metalloproteinase-9 overexpression is closely related to poor prognosis in patients with colon cancer. World J Surg Oncol 12: 24, 2014.

39. Seo EY and Kim WK: Red ginseng extract reduced metastasis of colon cancer cells in vitro and in vivo. J Ginseng Res 35: 315-324, 2011.

40. Deng W, Sui H, Wang Q, He N, Duan C, Han L, Li Q, Lu M and Lv S: A Chinese herbal formula, Yi-Qi-Fu-Sheng, inhibits migration/invasion of colorectal cancer by down-regulating MMP-2/9 via inhibiting the activation of ERK/MAPK signaling pathways. BMC Complement Altern Med 13: 65, 2013.

41. Zhao X, Sun P, Qian Y and Suo H: D. candidum has in vitro anticancer effects in HCT-116 cancer cells and exerts in vivo anti-metastatic effects in mice. Nutr Res Pract 8: 487-493, 2014.

42. Li BH, Zhao P, Liu SZ, Yu YM, Han M and Wen JK: Matrix metalloproteinase-2 and tissue inhibitor of metallo-proteinase-2 in colorectal carcinoma invasion and metastasis. World J Gastroenterol 11: 3046-3050, 2005.

43. Murnane MJ, Cai J, Shuja S, McAneny D, Klepeis V and Willett JB: Active MMP-2 effectively identifies the presence of colorectal cancer. Int J Cancer 125: 2893-2902, 2009.

44. Mroczko B, Groblewska M, Okulczyk B, Kędra B and Szmitkowski M: The diagnostic value of matrix metalloproteinase 9 (MMP-9) and tissue inhibitor of matrix metalloproteinases 1 (TIMP-1) determination in the sera of colorectal adenoma and cancer patients. Int J Colorectal Dis 25: 1177-1184, 2010.

45. Rayet B and Gélinas C: Aberrant rel/nfkb genes and activity in human cancer. Oncogene 18: 6938-6947, 1999.

46. Dolcet X, Llobet D, Pallares J and Matias-Guiu X: NF-kB in development and progression of human cancer. Virchows Arch 446: 475-482, 2005.

47. Ohshima K, Sugihara M, Haraoka S, Suzumiya J, Kanda M, Kawasaki C, Shimazaki K and Kikuchi M: Possible immortalization of Hodgkin and Reed-Sternberg cells: Telomerase expression, lengthening of telomere, and inhibition of apoptosis by NF-kappaB expression. Leuk Lymphoma 41: 367-376, 2001.

48. Ghosh S and Karin M: Missing pieces in the NF-kappaB puzzle. Cell 109 (Suppl): S81-S96, 2002.

49. Tak PP and Firestein GS: NF-kappaB: A key role in inflammatory diseases. J Clin Invest 107: 7-11, 2001.

50. Van Antwerp DJ, Martin SJ, Verma IM and Green DR: Inhibition of TNF-induced apoptosis by NF-kappaB. Trends Cell Biol 8: 107-111, 1998.

51. Chen C, Edelstein LC and Gélinas C: The Rel/NF-kappaB family directly activates expression of the apoptosis inhibitor $\mathrm{Bcl}-\mathrm{x}(\mathrm{L})$. Mol Cell Biol 20: 2687-2695, 2000.

52. Lin A and Karin M: NF-kappaB in cancer: A marked target. Semin Cancer Biol 13: 107-114, 2003.

53. Tergaonkar V, Bottero V, Ikawa M, Li Q and Verma IM: IkappaB kinase-independent IkappaBalpha degradation pathway: Functional NF-kappaB activity and implications for cancer therapy. Mol Cell Biol 23: 8070-8083, 2003.

54. Lee CH, Jeon YT, Kim SH and Song YS: NF-kappaB as a potential molecular target for cancer therapy. Biofactors 29: 19-35, 2007. 